\title{
Rockburst Precursors and the Dynamic Failure Mechanism of the Deep Tunnel: A Review
}

\author{
Yulong Chen ${ }^{1,2}$, Junwen Zhang ${ }^{2}$, Jiahao Zhang ${ }^{2}$, Bin $\mathrm{Xu}^{2}$, Luji Zhang ${ }^{2}$ and Wenxin $\mathrm{Li}^{3, *}$ \\ 1 State Key Laboratory of Hydroscience and Engineering, Tsinghua University, Beijing 100084, China; \\ chenyulong@cumtb.edu.cn \\ 2 School of Energy and Mining Engineering, China University of Mining and Technology, \\ Beijing 100083, China; zhangjw@cumtb.edu.cn (J.Z.); zjhweirenminfuwu@163.com (J.Z.); \\ xubin18062899636@163.com (B.X.); z2208210718@outlook.com (L.Z.) \\ 3 Key Laboratory of Mining Disaster Prevention and Control, Shandong University of Science and Technology, \\ Qingdao 266590, China \\ * Correspondence: li17753299337@163.com
}

Citation: Chen, Y.; Zhang, J.; Zhang, J.; Xu, B.; Zhang, L.; Li, W. Rockburst Precursors and the Dynamic Failure Mechanism of the Deep Tunnel: A Review. Energies 2021, 14, 7548. https://doi.org/10.3390/en14227548

Academic Editor: Manoj Khandelwal

Received: 21 October 2021

Accepted: 10 November 2021

Published: 12 November 2021

Publisher's Note: MDPI stays neutral with regard to jurisdictional claims in published maps and institutional affiliations.

Copyright: (c) 2021 by the authors. Licensee MDPI, Basel, Switzerland. This article is an open access article distributed under the terms and conditions of the Creative Commons Attribution (CC BY) license (https:// creativecommons.org/licenses/by/ $4.0 /)$.

\begin{abstract}
With the rapid development of underground caverns in the fields of hydraulic engineering, mining, railway and highway, the frequency, and intensity of rockburst and dynamic instability have gradually increased, which has become a bottleneck restricting the safe construction of deep caverns. This paper presents a review of the current understanding of rockburst precursors and the dynamic failure mechanism of the deep tunnel. Emphasis is placed on the stability of the surrounding rock of the deep tunnel, the rockburst prediction method, and the dynamic failure characteristics of the surrounding rock of the deep tunnel. Throughout the presentation, the current overall gaps in understanding rockburst precursors and the dynamic failure mechanism of deep tunnels are identified in an attempt to stimulate further research in these promising directions by the research community.
\end{abstract}

Keywords: rockburst; stability; deep tunnel; dynamic failure

\section{Introduction}

China has experienced a rapid development in high-speed rail over the past 15 years, and the national network has reached $35,000 \mathrm{~km}$ in total length since 2019. Railways in the mountainous areas are made up of tunnels. By the end of 2019, more than 16,000 railway tunnels (total length of 18,041 km) were fully operational in China. Meanwhile, more than 3200 tunnels (total length of $7975 \mathrm{~km}$ ) were in the planning stages [1,2]. Additionally, a large number of subway tunnels, utility tunnels, and diversion tunnels are currently under construction. Thus, tunnels are being constructed at an annual increasing rate of $7 \%$ worldwide for the next 5 to 10 years (equating to $5200 \mathrm{~km}$ of tunnels being built every year) [3].

The increase in underground engineering can result in the consequent increment of geohazards, and one representative example is the rockburst. Rockburst is a dynamic geological disaster associated with the spalling, fragmentation, and ejection of rock due to the sudden and violent release of elastic energy stored in the hard and brittle surrounding rock under excavation or other loading disturbances. Rockbursts occur frequently and violently with the increase of excavation depth [4-9]. Rockburst not only poses a severe threat to mine workers and mechanical equipment, but also delays the construction period and causes great economic losses.

Rockburst and the dynamic failure of surrounding rock have become a major problem in deep underground tunnels [10-12]. According to incomplete statistics, in China, a total of 660 rock bursts have occurred and 224 people have died in the past 10 years [13]; in the United States, a total of 172 bursts have occurred between 1936 and 1993, resulting in a 
total of 87 fatalities and 163 injuries [14]. However, it should be mentioned that, although more and more attention has been drawn to the research on rockburst in the past decades, the review concerning rockburst precursors and the dynamic failure mechanism of the deep tunnel is rather limited in number and scope. It is thus the intention of this study to comprehensively review the rockburst precursors and the dynamic failure mechanism of the deep tunnel. In doing so, a reference can be offered for the rockburst precursors and the dynamic failure mechanism of the deep tunnel in the future.

This review is organized as follows: Section 2 presents a review of the stability of the surrounding rock of the deep tunnel. Section 3 reviews the studies for rockburst prediction methods. Section 4 presents the work applying numerical simulation techniques and laboratory tests for the investigation of the dynamic failure characteristics of surrounding rock of deep tunnels. Section 5 concludes the review and suggests future research directions.

\section{Stability of the Surrounding Rock of the Deep Tunnel}

Scholars have conducted plenty of work on the instability mechanisms, influential factors, and the prevention measures of rock mass in tunnels under high stress by theoretical analysis, laboratory experiment, physical model test, field monitoring, and numerical simulation, and have achieved a lot of useful results. Zhu et al. [15] proposed a constitutive model to describe the rock creep with a logarithmic function. Thus, the stability of the surrounding rock of the underground circular tunnel was analyzed mechanically, and the relationship between the artificial support structure and the surrounding rock was discussed, and the result derived was a characteristic equation. Goodman and Shi [16] established a block theory for evaluating the stability of discontinuous massive rock masses. Zhang et al. [17] used a finite element method to identify unstable blocks and evaluate the stability of underground caverns. The Underground Research Laboratory of the Atomic Energy of Canada Limited carried out a series of field tests to study the damage process of surrounding rock under excavation unloading and revealed the factors affecting the stability of the surrounding rock of underground caverns [18-20]. Meng et al. [21] carried out shear tests for the prediction of rockburst hazards induced by dynamic structural plane shearing in deep hard rock tunnels, which was used to simulate the fault-slip rockburst and proposed a slip-type rockburst based on the evolution characteristics of the AE bvalue method of prediction. Liang et al. [22] used far infrared and AE technologies to monitor the progressive failure of a rock tunnel model under biaxial stress. Gong et al. [23] conducted large scale true triaxial tests on the red sandstone samples with a prefabricated hole for understanding the mechanism of slab buckling rockburst in deep tunnels in hard rock. Liu et al. [24] studied the AE activities of coarse-grained granite and fine-grained sandstone with prefabricated square and round holes under uniaxial loading. The simplex positioning algorithm was used to study the temporal and spatial evolution of AE in the process of rock rupture, and the characteristics of the AE activity, energy release rate, and spatial correlation length were analyzed. Verma and Singh [25] used a numerical model to predict the deformation and stability of the tunnel to be excavated. Saiang [26] used the discrete-continuous coupling method to analyze the development and characteristics of the rock mass explosion damage zone. Shreedharan and Kulatilake [27] used the discrete element method to study the stability of two deep coal mine roadways under high stress. Cai et al. [28] utilized the FLAC/PFC coupled method to study the AE activities in underground excavations at the Kannagawa underground powerhouse cavern in Japan.

With the development of computer technology, some scholars have introduced artificial intelligence algorithms such as neural networks, genetic algorithms, and deep learning to analyze the stability of the tunnel surrounding rock. Yang and Zhang [29] introduced a hierarchical analytical method based on the neural networks to identify the important degree of factors which controlled the stability of underground openings so as to recognize the key factors. Feng et al. [30] used a data mining method to judge the stability of the surrounding rock of underground caverns. 
Since the introduction of the New Austrian Tunnelling Method from the 1960s, surrounding rock monitoring and measurement technologies have been widely applied and developed as an important basis for determining the stability of surrounding rock [31-35]. This technology mainly uses strain gauges, stress gauges, multipoint displacement gauges, etc., to closely monitor the changes in surrounding rock strain, stress, and displacement during construction, thereby determining the corresponding support timing and support plan, ultimately realizing dynamic construction. However, this technology can only obtain the local displacement and stress information in the rock mass, and it cannot give a comprehensive evaluation of the overall stability of the rock mass structure. Meanwhile, it cannot monitor the development and evolution of microfractures inside the rock mass, so it cannot capture the precursor information of the macroscopic failure of the rock mass. Microseismic monitoring technology, as a space monitoring technology capable of capturing microfractures in the rock masses, is widely used in various tunnels [36-43], mines [44-48], rock slopes [49,50], and unconventional oil and gas exploration [51], carbon dioxide storage [52], and other fields. It is used to identify potential failure zones in rock mass engineering, so as to achieve the early warning and forecast of rock mass damage [53-55]. During the rock mass failure, the energy accumulated inside is released in the form of stress waves, causing microseismic signals $[56,57]$. By monitoring, analyzing, and processing the microseismic signals, the time, the spatial location, and the intensity of the microseismic signals can be obtained, and then qualitative and quantitative evaluations of regional rock mass stability can be made.

The above research results have laid a good foundation for further understanding of the failure characteristics and instability mechanisms of the surrounding rock of deep underground caverns under complex conditions. With the emergence of a large number of deep underground caverns in various fields, the occurrence environment of deep rock masses has undergone major changes compared to shallow rock masses, which are mainly manifested by high ground stress, high ground temperature, high karst water pressure, and strong dynamic disturbance. On the one hand, the high ground stress environment has brought many deep engineering disasters, among which rockbursts are the most prominent and cause the most serious damage, often causing serious personal injuries and deaths, equipment damage, and huge economic losses. On the other hand, under the strong dynamic disturbance, the mechanical characteristics of deep rock masses and the nonlinearity, uncertainty, and complexity of failure modes have become more prominent, and the frequency and intensity of dynamic disasters in the surrounding rock of deep underground caverns have increased significantly. The stability of the surrounding rock of deep caverns has become the focus of attention of scholars. However, the existing theories and methods still lag behind engineering practice and cannot provide effective guidance for engineering. Rockburst and the dynamic instability of surrounding rock have become key issues that restrict the safety of deep engineering construction. It is urgent for further research on the mechanism of rockburst prediction and the dynamic failure of surrounding rock under complex deep environments.

\section{Rockburst Prediction Method}

Since the first recorded rockburst in a British tin mine in 1738, scholars have carried out a lot of research in theory, experiment, numerical simulation, and other aspects, trying to understand the mechanism of rockburst and its influential factors, and on this basis to realize the prediction and early warning of rockburst [58-70]. Scholars have explored the mechanism of rockburst from the perspectives of stress [71], energy [72-74], stiffness [75,76], instability [77], and fractal [78], and put forward the corresponding prediction index of rockburst. According to different occurrence mechanisms, Kaiser [79] divided rockburst into two categories: spontaneous rockburst and remote disturbance-induced rockburst. The former is mainly related to the sudden release of the elastic energy accumulated in the surrounding rock under excavation unloading, while the latter is caused by the disturbance (blasting, mechanical vibration, rockburst stress, earthquake, etc.), and the damage caused 
by the disturbance is usually a certain distance away [80,81]. Yan et al. [82] found that disturbances due to excavation, particularly blasting excavation, have a significant impact on the scale and intensity of rockbursts, and summarized the rockburst prevention and control methods based on blasting technology. Li and Weng [83] numerically studied the dynamic fracturing behavior of underground caverns subjected to static geo-stress and dynamic loading. Li et al. [84] pointed out that deep underground engineering rock mass is inevitably affected by mechanical drilling, blasting, and other dynamic disturbances, and the influence of dynamic disturbances should be considered when studying rockburst. $\mathrm{Li}[85]$ summarized the current situation of rockburst support and put forward the ideas of rockburst control.

A large number of rockburst cases show that the occurrence of rockburst needs to meet two basic conditions: (1) the surrounding rock is hard, brittle, and relatively complete, and can store a large amount of elastic strain energy [86]; (2) high stress environment (including in situ stress and induced stress) [87-90], where the former is the internal cause of rockburst, and the latter is the external cause.

The above research has improved the understanding of rockburst and laid a foundation for the implementation of rockburst prediction and prevention measures in practical engineering. Rockburst prediction is the basis of reducing and even eliminating rockburst hazards and is an important basis for guiding engineering construction. Due to the complexity of the rockburst mechanism and its influencing factors, the prediction methods of rockburst are not mature and still need to be improved, which can be roughly divided into three categories [60-65]: (1) theoretical criteria, (2) case analysis, and (3) field monitoring-based rockburst prediction methods.

\subsection{Theoretical Criteria-Based Rockburst Prediction Method}

The theoretical criteria-based rockburst prediction method mainly uses various criteria, including stress [71], brittleness, energy [72-74], and stiffness [75,76], etc., which contributes to the rockburst mechanism to judge the rockburst tendency of engineering the surrounding rock. The widely used indexes are mainly the stress intensity ratio, the brittleness coefficient, the rockburst proneness index, the impact energy index, and the modified brittleness index, etc. These indexes are the basis for evaluating and predicting rockburst risk, and are mainly determined by field geological survey, in situ stress measurement and analysis, and in laboratory rock mechanics tests. These methods are mainly used in project planning, design, and the preliminary analysis and prediction of rockburst tendency in the construction stage [91,92].

\subsubsection{Stress Criteria}

The stress criteria are based on the intensity stress ratio (the ratio of the uniaxial compressive strength of rock to the stress of surrounding rock) or the stress intensity ratio (the ratio of the stress of surrounding rock to the uniaxial compressive strength of rock) to judge the occurrence and grade of rockburst. Commonly used stress criteria mainly include Tao Zhenyu criteria [71], Erlangshan Highway tunnel criteria [93], Norwegian Barton criteria [94], Russense criteria [95], Turchaninov criteria [96], Hoek criteria [97], etc., as shown in Table 1. These criteria are proposed based on different engineering cases, so the classification standards of rockburst are different, as well as the physical parameters used to characterize the surrounding rock stress. The commonly used physical parameters mainly include maximum shear stress, maximum principal stress, and axial stress.

\subsubsection{Brittleness Coefficient}

Brittleness is a significant property of rock and is the key internal cause of the rockburst of deep buried hard rock under high stress. Based on different purposes and applicable objects, scholars have proposed many rock brittleness coefficients. In 1974, Hucka and Das [98] summarized the brittleness coefficients, and Zhou et al. [99] further analyzed and summarized the characteristics of different brittleness coefficients. The brittleness 
coefficients, i.e., the ratio of uniaxial compressive strength to uniaxial tensile strength ( $B_{1}=\sigma_{c} / \sigma_{t}, \sigma_{c}$ is the uniaxial compressive strength of rock, $\sigma_{t}$ is the tensile strength) [100] and the ratio of the difference between the uniaxial compressive strength and tensile strength to their sum $\left(\left(B_{2}=\left(\sigma_{c}-\sigma_{t}\right) /\left(\sigma_{c}+\sigma_{t}\right)\right)\right.$ [101], have been widely used for the evaluation of rockburst proneness. Peng et al. [100] and Wang et al. [102] pointed out that the smaller the $B_{1}$, the more violent the rockburst, and proposed the rockburst intensity classification standard based on $B_{1}$. However, Zhang et al. [97,103] and Li et al. [104] found that the larger the $B_{1}$, the larger the rockburst proneness, and they also proposed corresponding rockburst classification standards. The two discrimination criteria are contradictory and are listed in Table 2.

Table 1. Stress criteria for rockburst prediction.

\begin{tabular}{ccccccc}
\hline \multirow{2}{*}{$\begin{array}{c}\text { Rockburst } \\
\text { Criteria }\end{array}$} & $\begin{array}{c}\text { Erlangshan Highway } \\
\text { Tunnel }\end{array}$ & $\begin{array}{c}\text { Tao Zhenyu } \\
\text { Criteria }\end{array}$ & Hoek & Turchaninov & Russense & Barton \\
\cline { 2 - 6 } & $\sigma_{\theta} / \boldsymbol{R}_{\boldsymbol{c}}$ & $\boldsymbol{R}_{\boldsymbol{c}} / \sigma_{\max }$ & $\sigma_{\theta} / \boldsymbol{R}_{\boldsymbol{c}}$ & $\left(\sigma_{\theta}+\sigma_{L}\right) / \boldsymbol{R}_{\boldsymbol{c}}$ & $\sigma_{\theta} / \boldsymbol{R}_{\boldsymbol{c}}$ & $\boldsymbol{R}_{\boldsymbol{c}} / \sigma_{\max }$ \\
\hline No & $<0.3$ & $>14.5$ & 0.34 & $<0.3$ & $<0.2$ & $>5$ \\
Weak & $0.3-0.5$ & $14.5-5.5$ & 0.42 & $0.3-0.5$ & $0.2-0.3$ & $2.5-5$ \\
Medium & $0.5-0.7$ & $5.5-2.5$ & 0.56 & $0.5-0.8$ & $0.3-0.55$ & $>0.55$ \\
Strong & $>0.7$ & $<2.5$ & $>0.7$ & $>0.8$ & $<2.5$ \\
\hline
\end{tabular}

Note: $R_{c}$ is the uniaxial compressive strength of rock, $\sigma_{\max }$ is the maximum principal stress, $\sigma_{\theta}$ is the maximum tangential stress, and $\sigma_{L}$ is the axial stress.

Table 2. Rockburst classification criteria based on brittleness coefficient $B_{1}$.

\begin{tabular}{ccccc}
\hline Classification Criteria & No & Weak & Medium & Strong \\
\hline Peng et al. [101], Wang et al. [102] & $>40$ & $26.7 \sim 40$ & $14.5 \sim 26.7$ & $<14.5$ \\
Zhang et al. [97,103] & $<15$ & $15 \sim 18$ & $18 \sim 22$ & $>22$ \\
Li et al. [104] & $<10$ & \multicolumn{2}{c}{$10 \sim 18$} & \\
\hline
\end{tabular}

\subsubsection{Energy Criteria}

The storage capacity of elastic strain energy in rock mass is an important internal cause of rockburst. Cook [105] first established the relationship between rock mass residual potential energy and rockburst disaster. Subsequently, scholars began to study rockburst from the view of energy storage and release, and proposed many energy-based rockburst discrimination indexes, such as the commonly used elastic energy index [106], improved brittleness index [74], and impact energy index.

Neyman [106] proposed an elastic energy index to determine the level of rockburst based on laboratory uniaxial loading and unloading tests. The index $W_{\text {et }}$ was defined as the ratio of the elastic energy released during unloading $\Phi_{\mathrm{sp}}$ to the dissipated plastic strain energy $\Phi_{\text {st }}$. It is mathematically given as

$$
W_{\mathrm{et}}=\Phi_{\mathrm{sp}} / \Phi_{\mathrm{st}}
$$

In order to obtain the value of $W_{\text {et }}$, a series of tests were first carried out to determine the average uniaxial compressive strength of the rock sample. On this basis, the uniaxial compression loading and unloading tests were conducted. Rock samples were loaded to 80-90\% of their average uniaxial compressive strength, and then unloaded, as shown in Figure 1. The greater the $W_{\text {et }}$ value, the greater the rockburst proneness [107].

In such tests, it started to unload when the load reached $80-90 \%$ of peak strength. However, due to the heterogeneity of rock mass, the unloading stress determined by this method and its peak strength may vary greatly with different samples, which greatly affected the accurate acquisition of $W_{\text {et }}$. To solve this problem, Aubertin [74] proposed an improved brittleness index (BIM), which was also calculated based on uniaxial compression tests in which unloading was not required. The calculation diagram is shown in Figure 2. The loading was up to the peak stress, and the unloading curve was the straight line that 
passed through the peak stress point as the slope of the elastic modulus at the half of the peak strength. The improved brittleness index (BIM) can be calculated by Equation (2).

$$
B I M=A_{1} / A_{3}
$$

where $A_{1}$ is the area under the loading curve and represents the total strain energy in the rock sample under uniaxial compression; $A_{3}$ is the area under the assumed unloading curve passing through the peak point. $A_{3}$ represents the peak elastic strain energy stored in the rock sample. The value of BIM is greater than or equal to 1 , and a smaller BIM value means larger elastic energy released and higher rockburst proneness. The evaluation criteria of rockburst proneness based on BIM are shown in Table 3.

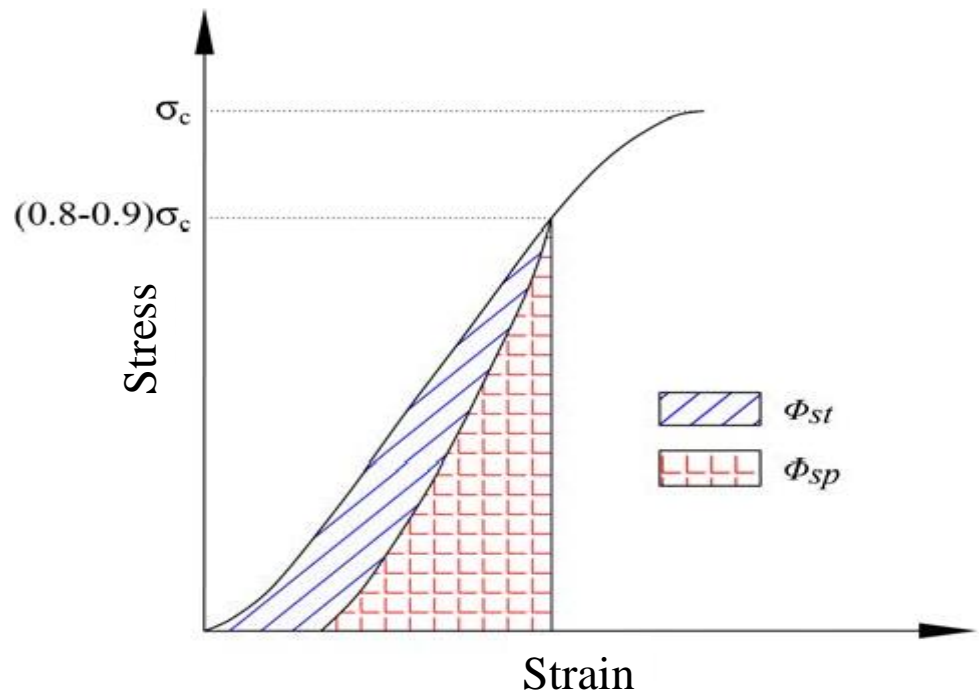

Figure 1. Schematic diagram of $W_{\text {et }}$ calculation based on uniaxial loading and unloading tests.

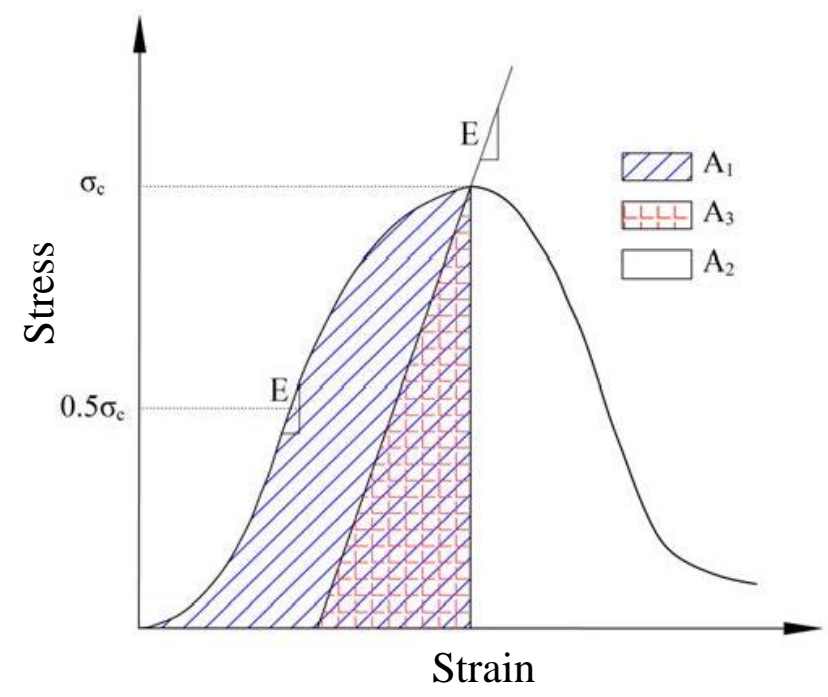

Figure 2. Calculation diagram of BIM and $F$ based on uniaxial compression test.

Table 3. Evaluation criteria of rockburst proneness based on BIM.

\begin{tabular}{cc}
\hline $\boldsymbol{B I M}$ & Rockburst Proneness \\
\hline $1.0-1.2$ & Strong \\
$1.2-1.5$ & Medium \\
$>1.5$ & Weak \\
\hline
\end{tabular}


Impact energy index $(F)$ is also based on the complete stress-strain curve of rock samples under uniaxial compression and is defined as the ratio of stored energy before the peak to that after the peak, as shown in Equation (3).

$$
F=A_{1} / A_{2}
$$

where $A_{1}$ is the area under the pre-peak stress-strain curve, and $A_{2}$ is the area under the post-peak stress-strain curve. For brittle rocks, the $F$-value is greater than 1 , that is, the stored energy is greater than the dissipated energy, indicating that the rockburst may occur. The larger the $F$-value, the more violent the rockburst.

\subsection{Case Analysis-Based Intelligent Method}

The case analysis-based prediction method of rockburst is mainly based on the heuristic algorithm [108], machine learning methods [109-111], data mining technology [112,113], and other mathematical tools, by analyzing a large number of engineering rockburst cases and considering multiple factors to establish a comprehensive prediction method of rockburst. Compared with the theoretical criteria-based rockburst prediction method, the case analysis-based prediction method takes into account the comprehensive functions of many factors, so that the calculation results are more reliable. In these methods, stress, strength, and energy-related parameters are usually used as input factors and the actual rockburst intensity as output parameters. Based on a large number of rockburst case data, the algorithm is continuously trained and optimized, and the correlation between the input factors and the output parameters is established to predict the possibility of rockburst in target engineering. The accuracy and reliability of this method mainly depend on the quantity and quality of the case data [114].

Recently, with the emergence of a large number of rockburst disasters in hydraulic engineering, transportation, mining, and other fields, as well as the rapid development of artificial intelligence methods like machine learning, the case analysis-based intelligent method has been further developed. Li et al. [110] proposed a rockburst prediction method based on the theory of logistic regression classifiers. Adoko et al. [112] developed five different fuzzy inference systems for rockburst prediction based on a fuzzy reasoning system, an adaptive neural fuzzy reasoning system, and field measurement data. Gong et al. [115] established a comprehensive distance discriminant model of rockburst intensity classification and prediction that considered the lithology, stress level, and energy of the surrounding rock. Ge et al. [116] proposed a new method based on the combination of artificial neural networks (ANN) classifiers as weak classifiers by using the AdaBoost algorithm in data mining. Wang et al. [117] established a new model for predicting the classification of rockburst based on the efficacy coefficient method by considering the key influential factors of rockburst comprehensively. Based on the technique for order preference by similarity to ideal solution, Zhou et al. [118] chose five indices, including uniaxial compressive strength $\sigma_{\mathrm{c}}$, the ratio of rock compressive tensile strength $\sigma_{\mathrm{c}} / \sigma_{\mathrm{t}}$, the stress coefficient of rock $\sigma_{\theta} / \sigma_{\mathrm{c}}$, the elastic energy index of rock $W_{\mathrm{et}}$, and the integrality coefficient $K_{\mathrm{V}}$ as the predictor variables of rockburst. Twenty rockburst cases were taken as the training and testing samples, according to the classification standard of rockburst, the supports, and weighs of the predictor variables were calculated by rough set theory, and the RS-TOPSIS model of rockburst prediction was established. Dong et al. [119] established a random forest model for predicting rockburst proneness. Zhou et al. [120] used ten supervised learning algorithms to predict rockburst based on 246 rockburst cases and compared the prediction results of different algorithms. Afraei et al. [113,121,122] established several rockburst proneness evaluation models based on the evaluation of different influencing factors.

\subsection{Field Monitoring-Based Rockburst Prediction Method}

The field monitoring-based rockburst prediction method mainly includes the microgravity method [123], the electromagnetic radiation method [124], the drilling cuttings method, the AE method [125], the electrical resistance method [126], the computed tomog- 
raphy method [127], and the microseismic monitoring method [128-130]. These methods watch the changes in a physical parameter, like stress and strain, resistance, microseismicity, $\mathrm{AE}$, electromagnetic radiation, etc., to indirectly reflect the changes of physical and mechanical properties of rock mass during construction and mining. In this way, the corresponding relationship between the monitoring information and the rock mass stability is established, and the evolution of the monitoring physical parameter during the development process of rockburst is further obtained, which can be used as the precursor information of rockburst so as to predict the occurrence of rockburst. The most important advantage of the field monitoring method is that it can receive feedback information in time, so as to effectively guide the construction and ensure the project safety. Among these methods, microseismic monitoring technology has been widely used in all kinds of underground engineering and has been proved to be an effective tool to reveal the mechanism of rockburst and give predictions [131-136]. Microseismic monitoring can obtain the time, location, and intensity of fracture in rock mass. Most importantly, it can locate the rock mass instability zone [137]. Based on the microseismic monitoring technology, scholars have carried out a large number of studies on the rockburst development process and obtained the microseismic precursor information about the evolution of microseismic parameters, such as the microseismic event number, cumulative released energy, $b$-value, and the spectrum characteristics of the microseismic waveform, etc. [138].

The above methods have enriched the knowledge of rockburst prediction. However, due to the complexity of the rockburst mechanism and the influencing factors, accurate rockburst prediction is still challenging and the current accuracy cannot effectively meet the needs of the safe construction of a deep hard rock underground cavern. Further exploration and development of rockburst prediction methods are needed.

\section{Dynamic Failure Characteristics of Surrounding Rock of Deep Tunnels}

The surrounding rock of deep underground caverns is subjected to numerous dynamic disturbances caused by blasting, earthquakes, rock caving, and excavation, besides gravity and tectonic stress. For deep rock mass, because the stress concentration around the cavern is more significant, the influence of dynamic disturbance on the stability of the surrounding rock is more prominent. With the continuous increase of the depth of underground caverns, more and more attention has been paid to the stability of the surrounding rock of deep tunnels under dynamic disturbance [139-143]. Li et al. [83] used FLAC3D software to simulate the characteristics of the strain energy density and the fracturing zone of tunnels under dynamic disturbance with different lateral pressure coefficients. Manouchehrian and Cai [144] used Abaqus to study the influence of weak planes on rockburst occurrence in tunnels under static and dynamic loadings. Zhu et al. [145] used the RFPA-Dynamics to simulate the rockburst caused by coupled static geo-stress and dynamic disturbance around the deep underground opening and indicated that the dynamic disturbance was one of the most important triggers responsible for the rockbursts around the underground opening. Yilmaz and Unlu [146] used FLAC3D to simulate the damage development of rock mass under blasting loading. Yan et al. [147] used PFC to analyze the characteristics of the surrounding rock damage zone of a deep tunnel under blasting excavation loading and in situ stress transient unloading, respectively. Lu et al. [148] investigated the process of release of in situ stress accompanying rock fragmentation by blasting to determine the dynamic response of reserved surrounding rock mass, such as vibration. Lu et al. [149] studied the influence of the thickness and strength of overburden strata on the rockburst failure process of an underground roadway by using UDEC.

Numerical methods are used to study the failure characteristics of underground caverns under dynamic disturbance, and the influence of different factors of dynamic disturbance (amplitude, duration, applied direction, etc.) on the stability of underground caverns. However, due to the combined high static stress and dynamic disturbance, the uncertainty and complexity of mechanical behavior, the deformation and failure mechanism 
of rock engineering will become more prominent, which will undoubtedly restrain the accuracy of numerical simulation and bring huge challenges to numerical methods.

Laboratory tests can visually reflect the mechanical properties, deformation, and failure evolution and stability characteristics of rock mass, and obtain visual knowledge that cannot be obtained by numerical simulation and verify the numerical simulation results [150-155]. Therefore, many scholars have investigated the dynamic failure characteristics of the surrounding rock based on laboratory tests. Liu et al. [156,157] carried out impact rockburst test on sandstone samples with a central hole under true triaxial static loading and vertical dynamic loading to analyze the fragmentation characteristics of the sandstone fragments. Du et al. [158] studied the failure behaviors of granite, red sandstone, and cement mortar under true triaxial unloading and then local dynamically disturbed loading and found that the rockburst and slabbing were closely related to the rock type, stress path, and dynamic disturbance. Su et al. $[159,160]$ compared the ramp and cyclic dynamic disturbances-induced rockbursts in terms of the failure phenomenon, damage evolutions, and energy characteristics under true triaxial conditions with a low-intermediate strain rate of $2 \sim 5 \%$ /s.

However, the dynamic loading used in the above tests are all cyclic loading with low strain rate and low amplitude, and the failure characteristics of the samples under such loading are affected by fatigue characteristics, which are significantly different from those under dynamic disturbance with a high strain rate [161,162]. Many scholars have experimentally studied the dynamic mechanical properties and failure characteristics of rock-like materials under the combined action of high static stress and high strain rate impact loading [163-166]. For instance, Tang et al. [167] conducted the dynamic response tests of a polymethylmethacrylate simulated tunnel under coupled biaxial static stress and high strain rate dynamic disturbance. Li et al. [168] observed the crack propagation of polymethylmethacrylate semicircular arch roadway specimens under stress wave loading. However, the dynamic failure characteristics of deep underground caverns under high static stress and high strain rate dynamic disturbance should be further systematically investigated in future research for better application in deep rock engineering practice.

\section{Conclusions and Future Perspective}

A comprehensive review was performed on the rockburst precursors and dynamic failure mechanisms of surrounding rock. The research presented in this review has been widely accepted and applied in engineering practices involving tunnel, cavern, and roadway stability problems. However, they have some weaknesses due to the complexity of rockburst and the uncertainty of the influencing factors, and hence require improvements in some respects.

(1) Due to the complexity of the mechanism and the influencing factors of rockburst, rock physical and mechanical properties, and the environment of deep rock mass, the accurate forecasting rock burst is still challenging. The accuracy of rock burst prediction methods could not effectively meet the needs of underground cavern construction in deep hard rock. Further exploration and development of rock burst prediction methods are required;

(2) The accuracy and reliability of the case analysis-based rockburst prediction method mainly depended on the quantity and quality of rockburst cases. Current studies are commonly based on tens of rockburst cases; thus, the reliability and applicability of the established prediction model are not satisfied. Recently, a large number of rockburst disasters have emerged in the fields of hydraulic engineering, transportation, and mining, and artificial intelligence methods, such as machine learning, have been rapidly developed. The increasing number of rockburst cases and the rapid development of artificial intelligence methods lay the foundation for the further development of the case analysis-based rockburst prediction methods. Therefore, it is necessary to establish a new case analysis-based rockburst prediction method by applying machine learning in rockburst case analyses; 
(3) To study the dynamic failure mechanism of surrounding rock, numerical simulations are mainly used. However, under the combined action of high static stress and dynamic disturbance, the uncertainty and complexity of mechanical behavior, the deformation and failure mechanism of rock engineering become more prominent, which will undoubtedly restrain the accuracy of numerical simulation and bring huge challenges to numerical methods. On the other hand, laboratory tests can directly reflect the overall mechanical characteristics, deformation, and failure, and the stability characteristics of rock mass, and can obtain a direct understanding that cannot be obtained from numerical simulation, as well as verify the numerical simulation results. However, the dynamic loads used in the above tests are all periodic cyclic loads with low strain rate and low amplitude. The sample failure under such loading is affected by the fatigue characteristics, which is quite different from the failure caused by dynamic disturbance with a high strain rate. Therefore, it is necessary to further study the dynamic failure characteristics of surrounding rock under the combined action of high static stress and high strain rate dynamic disturbance.

Author Contributions: Conceptualization, Y.C. and J.Z. (Junwen Zhang); methodology, Y.C. and J.Z. (Junwen Zhang); writing-original draft preparation, Y.C., J.Z. (Jiahao Zhang), B.X., L.Z.; writing-review and editing, Y.C., J.Z. (Junwen Zhang), J.Z. (Jiahao Zhang), B.X., L.Z.; supervision, J.Z. (Junwen Zhang); project administration, Y.C., J.Z. (Junwen Zhang), W.L.; funding acquisition, Y.C. and J.Z. (Junwen Zhang). All authors have read and agreed to the published version of the manuscript.

Funding: This study is supported by the National Natural Science Foundation of China (52034009, 52009131), Beijing Natural Science Foundation (8204068), and the Open Research Fund Programs of State key Laboratory of Hydroscience and Engineering (sklhse-2020-C-02), Key Laboratory of Mining Disaster Prevention and Control (MDPC201918).

Institutional Review Board Statement: Not applicable.

Informed Consent Statement: Not applicable.

Data Availability Statement: The data used to support the findings of this study are available from the corresponding author upon request.

Conflicts of Interest: The authors declare no competing interest.

\section{References}

1. Xue, Y.G.; Kong, F.M.; Li, S.C.; Zhang, Q.S.; Qiu, D.H.; Su, M.X.; Li, Z.Q. China starts the world's hardest "Sky-High Road" project: Challenges and countermeasures for Sichuan-Tibet railway. Innovation 2021, 2, 100105. [CrossRef]

2. Tian, S.; Gong, J. Statistics of railway tunnels in China as of end of 2019. Tunn. Constr. 2020, 40, $292-297$.

3. Tsinidis, G.; de Silva, F.; Anastasopoulos, I.; Bilotta, E.; Bobet, A.; Hashash, Y.M.A.; He, C.; Kampas, G.; Knappett, J.; Madabhushi, G.; et al. Seismic behaviour of tunnels: From experiments to analysis. Tunn. Undergr. Space Technol. 2020, $99,103334$. [CrossRef]

4. Qian, Q.H. Definition, mechanism, classification and quantitative forecast model for rockburst and pressure bump. Rock Soil Mech. 2014, 35, 1-6.

5. Lu, C.P.; Dou, L.M.; Wu, X.R.; Wang, H.M.; Qin, Y.H. Frequency spectrum analysis on microseismic monitoring and signal differentiation of rock material. Chin. J. Geotech. Eng. 2005, 27, 772-775.

6. Li, T.B.; Wang, X.F.; Meng, L.B. Physical simulation study of similar materials for rockburst. Chin. J. Rock Mech. Eng. 2011, 30, 2610-2616.

7. Liu, B.; Zhao, Y.; Zhang, C.; Zhou, J.; Li, Y.; Sun, Z. Characteristic strength and acoustic emission properties of weakly cemented sandstone at different depths under uniaxial compression. Int. J. Coal Sci. Technol. 2021, 1-14. [CrossRef]

8. Zuo, J.; Wang, J.; Jiang, Y. Macro/meso failure behavior of surrounding rock in deep roadway and its control technology. Int. J. Coal Sci. Technol. 2019, 6, 301-319. [CrossRef]

9. Keneti, A.; Sainsbury, B.-A. Review of published rockburst events and their contributing factors. Eng. Geol. 2018, 246, 361-373. [CrossRef]

10. Kabwe, E.; Wang, Y. Review on Rockburst Theory and Types of Rock Support in Rockburst Prone Mines. Open J. Saf. Sci. Technol. 2015, 5, 104-121. [CrossRef]

11. He, M.; Xia, H.; Jia, X.; Gong, W.; Zhao, F.; Liang, K. Studies on classification, criteria and control of rockbursts. J. Rock Mech. Geotech. Eng. 2012, 4, 97-114. [CrossRef] 
12. Martin, C.D.; Christiansson, R. Estimating the potential for spalling around a deep nuclear waste repository in crystalline rock. Int. J. Rock Mech. Min. Sci. 2009, 46, 219-228. [CrossRef]

13. Cai, W.; Dou, L.; Si, G.; Cao, A.; He, J.; Liu, S. A principal component analysis/fuzzy comprehensive evaluation model for coal burst liability assessment. Int. J. Rock Mech. Min. Sci. 2016, 81, 62-69. [CrossRef]

14. Mark, C. Coal bursts in the deep longwall mines of the United States. Int. J. Coal Sci. Technol. 2016, 3, 1-9. [CrossRef]

15. Zhu, S.P.; Zhou, C.L. Viscoelastic Mechanical Analysis of Stability in Circular Underground Tunnels. J. Tongji Univ. 1994, 22, 329-333.

16. Goodman, R.E.; Shi, G. Block Theory and Its Application to Rock Engineering; Prentice-Hall: Englewood Cliffs, NJ, USA, 1985.

17. Zhang, Y.; Xiao, M.; Chen, J. A new methodology for block identification and its application in a large scale underground cavern complex. Tunn. Undergr. Space Technol. 2010, 25, 168-180. [CrossRef]

18. Read, R. 20 years of excavation response studies at AECL's Underground Research Laboratory. Int. J. Rock Mech. Min. Sci. 2004, 41, 1251-1275. [CrossRef]

19. Martino, J.; Chandler, N. Excavation-induced damage studies at the Underground Research Laboratory. Int. J. Rock Mech. Min. Sci. 2004, 41, 1413-1426. [CrossRef]

20. Chandler, N. Developing tools for excavation design at Canada's Underground Research Laboratory. Int. J. Rock Mech. Min. Sci. 2004, 41, 1229-1249. [CrossRef]

21. Meng, F.; Zhou, H.; Wang, Z.; Zhang, L.; Kong, L.; Li, S.; Zhang, C. Experimental study on the prediction of rockburst hazards induced by dynamic structural plane shearing in deeply buried hard rock tunnels. Int. J. Rock Mech. Min. Sci. 2016, 86, 210-223. [CrossRef]

22. Zhang, Y.B.; Liu, X.X.; Liang, Z.Z.; Li, Z.J. Analysis of Precursors Prior to Rock Burst in Granite Tunnel Using Acoustic Emission and Far Infrared Monitoring. Math. Probl. Eng. 2013, 2013, 214340.

23. Gong, F.Q.; Luo, Y.; Si, X.F.; Li, X.B. Experimental modelling on rockburst in deep hard rock circular tunnels. Chin. J. Rock Mech. Eng. 2017, 36, 1634-1648.

24. Liu, J.P.; Xu, S.D.; Li, Y.H.; Dong, L.B.; Wei, J. Studies of ae time-space evolution characteristics during failure process of rock specimens with prefabricated holes. Chin. J. Rock Mech. Eng. 2012, 31, 2538-2547.

25. Verma, A.K.; Singh, T. Assessment of tunnel instability-A numerical approach. Arab. J. Geosci. 2010, 3, 181-192. [CrossRef]

26. Saiang, D. Stability analysis of the blast-induced damage zone by continuum and coupled continuum-Discontinuum methods. Eng. Geol. 2010, 116, 1-11. [CrossRef]

27. Shreedharan, S.; Kulatilake, P.H.S.W. Discontinuum-Equivalent Continuum Analysis of the Stability of Tunnels in a Deep Coal Mine Using the Distinct Element Method. Rock Mech. Rock Eng. 2016, 49, 1903-1922. [CrossRef]

28. Cai, M.; Kaiser, P.; Morioka, H.; Minami, M.; Maejima, T.; Tasaka, Y.; Kurose, H. FLAC/PFC coupled numerical simulation of AE in large-scale underground excavations. Int. J. Rock Mech. Min. Sci. 2007, 44, 550-564. [CrossRef]

29. Yang, Y.; Zhang, Q. A hierarchical analysis for rock engineering using artificial neural networks. Rock Mech. Rock Eng. 1997, 30, 207-222. [CrossRef]

30. Feng, X.T.; Ma, P.B. Identifying stability of underground openings based on data mining. Chin. J. Rock Mech. Eng. 2001, 20, 306-309.

31. Sakurai, S.; Takeuchi, K. Back analysis of measured displacements of tunnels. Rock Mech. Rock Eng. 1983, 16, 173-180. [CrossRef]

32. Wu, Q.J.; Wang, M.N.; Liu, D.G. Research on stability of tunnel surrounding rocks based on statistical analysis of on-site displacement monitoring data. Rock Soil Mech. 2012, 33, 359-364.

33. Li, S.; Yu, H.; Liu, Y.; Wu, F. Results from in-situ monitoring of displacement, bolt load, and disturbed zone of a powerhouse cavern during excavation process. Int. J. Rock Mech. Min. Sci. 2008, 45, 1519-1525. [CrossRef]

34. Gao, W.; Ge, M. Back analysis of rock mass parameters and initial stress for the Longtan tunnel in China. Eng. Comput. 2016, 32, 497-515. [CrossRef]

35. Zhou, H.; Qu, C.K.; Hu, D.W.; Zhang, C.Q. Insitu monitoring of tunnel deformation evolutions from auxiliary tunnel in deep mine. Eng. Geol. 2017, 221, 10-15. [CrossRef]

36. Feng, X.; Chen, B.; Li, S.; Zhang, C.; Xiao, Y.; Feng, G.; Zhou, H.; Qiu, S.; Zhao, Z.; Yu, Y.; et al. Studies on the evolution process of rockbursts in deep tunnels. J. Rock Mech. Geotech. Eng. 2012, 4, 289-295. [CrossRef]

37. Dai, F.; Li, B.; Xu, N.; Fan, Y.; Zhang, C. Deformation forecasting and stability analysis of large-scale underground powerhouse caverns from microseismic monitoring. Int. J. Rock Mech. Min. Sci. 2016, 86, 269-281. [CrossRef]

38. Hirata, A.; Kameoka, Y.; Hirano, T. Safety Management Based on Detection of Possible Rock Bursts by AE Monitoring during Tunnel Excavation. Rock Mech. Rock Eng. 2007, 40, 563-576. [CrossRef]

39. Feng, G.L.; Feng, X.T.; -Chen, B.R.; Xiao, Y.X.; Zhao, Z.N. Effects of structural planes on the microseismicity associated with rockburst development processes in deep tunnels of the Jinping-II Hydropower Station, China. Tunn. Undergr. Space Technol. 2019, 84, 273-280. [CrossRef]

40. Feng, X.-T.; Yu, Y.; Feng, G.-L.; Xiao, Y.-X.; Chen, B.-R.; Jiang, Q. Fractal behaviour of the microseismic energy associated with immediate rockbursts in deep, hard rock tunnels. Tunn. Undergr. Space Technol. 2016, 51, 98-107. [CrossRef]

41. Hong, J.S.; Lee, H.S.; Lee, D.H.; Kim, H.Y.; Choi, Y.T.; Par, Y.J. Microseismic event monitoring of highly stressed rock mass around underground oil storage caverns. Tunn. Undergr. Space Technol. 2006, 21, 292. [CrossRef] 
42. Feng, G.-L.; Feng, X.-T.; Chen, B.-R.; Xiao, Y.-X. Microseismic sequences associated with rockbursts in the tunnels of the Jinping II hydropower station. Int. J. Rock Mech. Min. Sci. 2015, 80, 89-100. [CrossRef]

43. Dai, F.; Li, B.; Xu, N.; Zhu, Y. Microseismic early warning of surrounding rock mass deformation in the underground powerhouse of the Houziyan hydropower station, China. Tunn. Undergr. Space Technol. 2017, 62, 64-74. [CrossRef]

44. Wang, H.; Ge, M. Acoustic emission/microseismic source location analysis for a limestone mine exhibiting high horizontal stresses. Int. J. Rock Mech. Min. Sci. 2008, 45, 720-728. [CrossRef]

45. Ge, M. Efficient mine microseismic monitoring. Int. J. Coal Geol. 2005, 64, 44-56. [CrossRef]

46. Mendecki, A.J.; Lynch, R.A.; Malovichko, D.A. Routine micro-seismic monitoring in mines. In Proceedings of the Australian Earthquake Engineering Society Conference, Perth, Western Australia, Australia, 26-28 November 2010.

47. Lu, C.-P.; Liu, G.-J.; Liu, Y.; Zhang, N.; Xue, J.-H.; Zhang, L. Microseismic multi-parameter characteristics of rockburst hazard induced by hard roof fall and high stress concentration. Int. J. Rock Mech. Min. Sci. 2015, 76, 18-32. [CrossRef]

48. Potvin, Y.; Hudyma, M. Keynote address: Seismic monitoring in highly mechanized hardrock mines in Canada and Australia. In Proceedings of the Fifth International Symposium on Rockburst and Seismicity in Mines (Ra Si M 5), Johannesburg, South Africa, 17-19 September 2001; pp. 267-280.

49. Xu, N.; Dai, F.; Liang, Z.Z.; Zhou, Z.; Sha, C.; Tang, C.A. The Dynamic Evaluation of Rock Slope Stability Considering the Effects of Microseismic Damage. Rock Mech. Rock Eng. 2014, 47, 621-642. [CrossRef]

50. Occhiena, C.; Pirulli, M.; Scavia, C. A microseismic-based procedure for the detection of rock slope instabilities. Int. J. Rock Mech. Min. Sci. 2014, 69, 67-79. [CrossRef]

51. Cipolla, C.L.; Maxwell, S.C.; Mack, M.G. Engineering Guide to the Application of Microseismic Interpretations; Society of Petroleum Engineers: The Woodlands, TX, USA, 2012.

52. Stork, A.L.; Verdon, J.P.; Kendall, J.-M. Assessing the Effect of Velocity Model Accuracy on Microseismic Interpretation at the In Salah Carbon Capture and Storage Site. Energy Procedia 2014, 63, 4385-4393. [CrossRef]

53. Dai, F.; Li, B.; Xu, N.; Zhu, Y.; Xiao, P. Stability Evaluation on Surrounding Rocks of Underground Powerhouse Based on Microseismic Monitoring. Shock Vib. 2015, 2015, 937181. [CrossRef]

54. Xu, N.; Li, T.; Dai, F.; Li, B.; Zhu, Y.; Yang, D. Microseismic monitoring and stability evaluation for the large scale underground caverns at the Houziyan hydropower station in Southwest China. Eng. Geol. 2015, 188, 48-67. [CrossRef]

55. Ma, K.; Tang, C.A.; Liang, Z.H.; Wu, J.; Xu, N.W.; Zhuang, D.Y. Stability analysis of the surrounding rock of underground water-sealed oil storage caverns based on microseismic monitoring during construction. Chin. J. Rock Mech. Eng. 2016, $35,1353-1365$.

56. Hardy, H.R., Jr. Acoustic Emission/Microseismic Activity: Volume 1, Principles, Techniques and Geotechnical Applications; CRC Press: Boca Raton, FL, USA, 2005.

57. Zhang, S.C.; Ma, T.H.; Tang, C.A.; Jia, P.; Wang, Y.C. Microseismic Monitoring and Experimental Study on Mechanism of Delayed Rockburst in Deep-Buried Tunnels. Rock Mech. Rock Eng. 2020, 53, 2771-2788. [CrossRef]

58. Ortlepp, W.D.; Stacey, T.R. Rock burst mechanisms in tunnels and shafts. Tunn. Undergr. Space Technol. 1994, 59, 59-65. [CrossRef]

59. Feng, X.T.; Xiao, Y.X.; Feng, G.L.; Yao, Z.B.; Chen, B.R.; Yang, C.X.; Su, G.S. Study on the development process of rockbursts. Chin. J. Rock Mech. Eng. 2019, 38, 1-25.

60. Wang, J.-A.; Park, H. Comprehensive prediction of rockburst based on analysis of strain energy in rocks. Tunn. Undergr. Space Technol. 2001, 16, 49-57. [CrossRef]

61. Ortlepp, W. RaSiM Comes of Age-A Review of the Contribution to the Understanding and Control of Mine Rockbursts. In Proceedings of the Sixth International Symposium on Rockburst and Seismicity in Mines Proceedings, Perth, Australian, 9-11 March 2005; pp. 3-20.

62. Blake, W.; Hedley, D.G. Rockbursts: Case Studies from North American Hard-Rock Mines; Society for Mining, Metallurgy, and Exploration: Englewood, CO, USA, 2003.

63. Frid, V. Rockburst hazard forecast by electromagnetic radiation excited by rock fracture. Rock Mech. Rock Eng. 1997, 30, 229-236. [CrossRef]

64. Li, S.; Feng, X.-T.; Li, Z.; Chen, B.; Zhang, C.; Zhou, H. In situ monitoring of rockburst nucleation and evolution in the deeply buried tunnels of Jinping II hydropower station. Eng. Geol. 2012, 137-138, 85-96. [CrossRef]

65. Lu, C.-P.; Dou, L.-M.; Zhang, N.; Xue, J.-H.; Wang, X.-N.; Liu, H.; Zhang, J.-W. Microseismic frequency-spectrum evolutionary rule of rockburst triggered by roof fall. Int. J. Rock Mech. Min. Sci. 2013, 64, 6-16. [CrossRef]

66. Hagan, T.O.; Milev, A.M.; Spottiswoode, S.M.; Hildyard, M.W.; Grodner, M.; Rorke, A.J.; Finnie, G.J.; Reddy, N.; Haile, A.T.; Le Bron, K.B.; et al. Simulated rockburst experiment-an overview. J. S. Afr. Inst. Min. Metall. 2001, 101, $217-222$.

67. He, M.C.; Nie, W.; Zhao, Z.; Guo, W. Experimental Investigation of Bedding Plane Orientation on the Rockburst Behavior of Sandstone. Rock Mech. Rock Eng. 2012, 45, 311-326. [CrossRef]

68. Gong, Q.; Yin, L.; Wu, S.; Zhao, J.; Ting, Y. Rock burst and slabbing failure and its influence on TBM excavation at headrace tunnels in Jinping II hydropower station. Eng. Geol. 2012, 124, 98-108. [CrossRef]

69. Su, G.; Jiang, J.; Zhai, S.; Zhang, G. Influence of Tunnel Axis Stress on Strainburst: An Experimental Study. Rock Mech. Rock Eng. 2017, 50, 1551-1567. [CrossRef]

70. Li, T.B.; Pan, H.S.; Chen, G.Q.; Lu, M.B. Physical model tests on thermo-mechanical effects in rockbursts around tunnels. Chin. J. Rock Mech. Eng. 2018, 37, 261-273. 
71. Tao, Z.Y. Support Design of Tunnels Subjected to Rockbursting; ISRM International Symposium: Madrid, Spain, 1988.

72. Kidybiński, A. Bursting liability indices of coal. Int. J. Rock Mech. Min. Sci. Géoméch. Abstr. 1981, 18, 295-304. [CrossRef]

73. Chen, B.-R.; Feng, X.-T.; Li, Q.-P.; Luo, R.-Z.; Li, S. Rock Burst Intensity Classification Based on the Radiated Energy with Damage Intensity at Jinping II Hydropower Station, China. Rock Mech. Rock Eng. 2015, 48, 289-303. [CrossRef]

74. Aubertin, M.; Gill, D.E.; Simon, R. On the use of the brittleness index modified (BIM) to estimate the post-peak behavior of rocks. In Proceedings of the 1st North American Rock Mechanics Symposium: Models and Measurements Challenges from Industry, Austin, TX, USA, 1-3 June 1994; pp. 945-952.

75. Cook, N.G.W. The failure of rock. Int. J. Rock Mech. Min. Sci. 1965, 2, 389-403. [CrossRef]

76. Tang, L.-Z.; Xia, K.W. Seismological method for prediction of areal rockbursts in deep mine with seismic source mechanism and unstable failure theory. J. Central South Univ. Technol. 2010, 17, 947-953. [CrossRef]

77. Linkov, A. Rockbursts and the instability of rock masses. Int. J. Rock Mech. Min. Sci. Géoméch. Abstr. 1996, 33, 727-732. [CrossRef]

78. Xie, H.; Pariseau, W. Fractal character and mechanism of rock bursts. Int. J. Rock Mech. Min. Sci. Géoméch. Abstr. 1993, 30, 343-350. [CrossRef]

79. Kaiser, P.K. Canadian Rockburst Support Handbook; Geomechanics Research Centre: Sudbury, CO, Canada, 1996.

80. Huang, R.Q.; Wang, X.N. Analysis of dynamic disturbance on rock burst. Bull. Int. Assoc. Eng. Geol. 1999, 57, 281-284. [CrossRef]

81. He, M.; e Sousa, L.R.; Miranda, T.; Zhu, G. Rockburst laboratory tests database-Application of data mining techniques. Eng. Geol. 2015, 185, 116-130. [CrossRef]

82. Yan, P.; Zhao, Z.; Lu, W.; Fan, Y.; Chen, X.; Shan, Z. Mitigation of rock burst events by blasting techniques during deep-tunnel excavation. Eng. Geol. 2015, 188, 126-136. [CrossRef]

83. Li, X.; Weng, L. Numerical investigation on fracturing behaviors of deep-buried opening under dynamic disturbance. Tunn. Undergr. Space Technol. 2016, 54, 61-72. [CrossRef]

84. Li, X.B.; Gong, F.Q.; Wang, S.F.; Li, D.Y.; Tao, M.; Zhou, J.; Huang, L.Q.; Ma, C.D.; Du, K.; Feng, F. Coupled static-dynamic loading mechanical mechanism and dynamic criterion of rockburst in deep hard rock mines. Chin. J. Rock Mech. Eng. 2019, 38, 708-723.

85. Li, C.L. Rockburst conditions and rockburst support. Chin. J. Rock Mech. Eng. 2019, 38, 674-682.

86. Cai, M.; Kaiser, P.; Martin, C.D. Quantification of rock mass damage in underground excavations from microseismic event monitoring. Int. J. Rock Mech. Min. Sci. 2001, 38, 1135-1145. [CrossRef]

87. Zhao, T.-B.; Guo, W.-Y.; Tan, Y.-L.; Yin, Y.-C.; Cai, L.-S.; Pan, J.-F. Case Studies of Rock Bursts Under Complicated Geological Conditions During Multi-seam Mining at a Depth of 800 m. Rock Mech. Rock Eng. 2018, 51, 1539-1564. [CrossRef]

88. Cai, M. Prediction and prevention of rockburst in metal mines-A case study of Sanshandao gold mine. J. Rock Mech. Geotech Eng. 2016, 8, 204-211. [CrossRef]

89. Kaiser, P.K.; Cai, M. Design of rock support system under rockburst condition. J. Rock Mech. Geotech. Eng. 2012, 4, 215-227. [CrossRef]

90. Martini, C.D.; Read, R.S.; Martino, J.B. Observations of brittle failure around a circular test tunnel. Int. J. Rock Mech. Min. Sci. 1997, 34, 1065-1073. [CrossRef]

91. Li, T.; Xiao, X.; Shi, Y. Comprehensive integrated methods of rockburst prediction in underground engineering. Adv. Earth Sci. 2008, 23, 533-540.

92. Ma, T.; Tang, C.; Tang, L.; Zhang, W.; Wang, L. Rockburst characteristics and microseismic monitoring of deep-buried tunnels for Jinping II Hydropower Station. Tunn. Undergr. Space Technol. 2015, 49, 345-368. [CrossRef]

93. Xu, L.S.; Wang, L.S. Study on the laws of rockburst and its forecasting in the tunnel of Erlang Mountain road. Chin. J. Rock Mech. Eng. 1999, 21, 569-572.

94. Barton, N.; Lien, R.; Lunde, J. Engineering classification of rock masses for the design of tunnel support. Rock Mech. Rock Eng. 1974, 6, 189-236. [CrossRef]

95. Russenes, B.F. Analysis of Rock Spalling for Tunnels in Steep Valley Sides (in Norwegian). Master's Thesis, Norwegian Institute of Technology, Trondheim, Norway, 1974.

96. Turchaninov, I.; Markov, G. Conditions of changing of extra-hard rock into weak rock under the influence of tectonic stresses of massifs. In Proceedings of the Paper presented at the ISRM International Symposium, Tokyo, Japan, 21-24 September 1981.

97. Zhang, J.J.; Fu, B.J. Rockburst and its criteria and control. Chin. J. Rock Mech. Eng. 2008, 27, $2034-2042$.

98. Hucka, V.; Das, B. Brittleness determination of rocks by different methods. Int. J. Rock Mech. Min. Sci. Géoméch. Abstr. 1974, 11, 389-392. [CrossRef]

99. Zhou, H.; Meng, F.Z.; Zhang, C.Q.; Xu, R.C.; Lu, J.J. Quantitative evaluation of rock brittleness based on stress-strain curve. Chin. J. Rock Mech. Eng. 2014, 33, 1114-1122.

100. Peng, Z.; Wang, Y.H.; Li, T.J. Griffith theory and the criteria of rock burs. Chin. J. Rock Mech. Eng. 1996, 15, 491-495.

101. Singh, S. The influence of rock properties on the occurrence and control of rockbursts. Min. Sci. Technol. 1987, 5, 11-18. [CrossRef]

102. Wang, Y.H.; Li, W.D.; Li, G.Q.; Xu, Y.; Tan, G.H. Method of fuzzy comprehensive evaluations for rockburst prediction. Chin. J. Rock Mech. Eng. 1998, 17, 15-23.

103. Zhang, J.; Fu, B.; Li, Z.; Song, S.; Shang, Y. Criterion and classification for strain mode rockbursts based on five-factor comprehensive method. Harmon. Rock Eng. Environ. 2011, 1435-1440. [CrossRef]

104. Li, S.L.; Feng, X.T.; Wang, Y.J.; Yang, N.G. Evaluation of Rockburst Proneness in a Deep Hard Rock Mine. J. Northeast. Univ. 2001, 22, 60-63. 
105. Cook, N.G.W. The basic mechanics of rockbursts. J. S. Afr. Inst. Min. Metall. 1963, 64, 71-81.

106. Neyman, B.; Szecowka, Z.; Zuberek, W. Effective methods for fighting rock burst in Polish collieries. In Proceedings of the 5th International Strata Control Conference, London, UK, 21-25 August 1972; pp. 1-9.

107. Kwasniewski, M.; Szutkowski, I.; Wang, J. Study of Ability of Coal from Seam 510 for Storing Elastic Energy in the Aspect of Assessment of Hazard in Porabka-Klimontow Colliery; Scientific Report; Silesian Technical University: Gliwice, Poland, 1994.

108. Zhou, J.; Li, X.; Shi, X. Long-term prediction model of rockburst in underground openings using heuristic algorithms and support vector machines. Saf. Sci. 2012, 50, 629-644. [CrossRef]

109. Pu, Y.Y.; Apel, D.B.; Wei, C. Applying Machine Learning Approaches to Evaluating Rockburst Liability: A Comparation of Generative and Discriminative Models. Pure Appl. Geophys. 2019, 176, 4503-4517. [CrossRef]

110. Li, N.; Jimenez, R. A logistic regression classifier for long-term probabilistic prediction of rock burst hazard. Nat. Hazards 2017, 90, 197-215. [CrossRef]

111. Feng, X.T.; Wang, L.N. Rockburst prediction based on neural networks. Trans. Nonferrous Met. Soc. China 1994, 4, 7-14.

112. Adoko, A.C.; Gokceoglu, C.; Wu, L.; Zuo, Q.J. Knowledge-based and data-driven fuzzy modeling for rockburst prediction. Int. J. Rock Mech. Min. Sci. 2013, 61, 86-95. [CrossRef]

113. Afraei, S.; Shahriar, K.; Madani, S.H. Statistical assessment of rock burst potential and contributions of considered predictor variables in the task. Tunn. Undergr. Space Technol. 2018, 72, 250-271. [CrossRef]

114. Li, N.; Jimenez, R.; Feng, X. The Influence of Bayesian Networks Structure on Rock Burst Hazard Prediction with Incomplete Data. Procedia Eng. 2017, 191, 206-214. [CrossRef]

115. Gong, F.Q.; Li, X.B. A distance discriminant analysis method for prediction of possibility and classification of rockburst and its application. Chin. J. Rock Mech. Eng. 2007, 26, 1012-1018.

116. Ge, Q.F.; Feng, X.T. Classification and prediction of rockburst using AdaBoost combination learning method. Rock Soil Mech. 2008, 29, 943-948.

117. Wang, Y.C.; Shang, Y.Q.; Sun, H.Y.; Yan, X.S. Study of prediction of rockburst intensity based on efficacy coefficient method. Rock Soil Mech. 2010, 31, 529-534.

118. Zhou, K.P.; Lei, T.; Hu, J.H. Rs-topsis model of rockburst prediction in deep metal mines and its application. Chin. J. Rock Mech. Eng. 2013, 32, 3705-3711.

119. Dong, L.-J.; Li, X.-B.; Peng, K. Prediction of rockburst classification using Random Forest. Trans. Nonferrous Met. Soc. China 2013, 23, 472-477. [CrossRef]

120. Zhou, J.; Li, X.; Mitri, H.S. Classification of Rockburst in Underground Projects: Comparison of Ten Supervised Learning Methods. J. Comput. Civ. Eng. 2016, 30, 4016003. [CrossRef]

121. Afraei, S.; Shahriar, K.; Madani, S.H. Developing intelligent classification models for rock burst prediction after recognizing significant predictor variables, Section 2: Designing classifiers. Tunn. Undergr. Space Technol. 2018, 84, 522-537. [CrossRef]

122. Afraei, S.; Shahriar, K.; Madani, S.H. Developing intelligent classification models for rock burst prediction after recognizing significant predictor variables, Section 1: Literature review and data preprocessing procedure. Tunn. Undergr. Space Technol. 2019, 83, 324-353. [CrossRef]

123. Fajklewicz, Z. Application of microgravimetry method to detection of subsurface cavities and prediction of rock bursts. Adv. Coal Geophys. EAG 1988, 1, 1-11.

124. Li, X.; Wang, E.; Li, Z.; Liu, Z.; Song, D.; Qiu, L. Rock Burst Monitoring by Integrated Microseismic and Electromagnetic Radiation Methods. Rock Mech. Rock Eng. 2016, 49, 4393-4406. [CrossRef]

125. Jansen, D.P.; Carlson, S.R.; Young, R.P.; Hutchins, D.A. Ultrasonic-Imaging and Acoustic-Emission Monitoring of ThermallyInduced Microcracks in Lac-Du-Bonnet-Granite. J. Geophys. Res.—Solid Earth 1993, 98, 22231-22243. [CrossRef]

126. Stopiński, W.; Dmowska, R. Rock resistivity in the Lubin (Poland) copper mine and its relation to variations of strain field and occurrence of rockbursts. In Proceedings of the 1st International Congress on Rockbursts and Seismicity in Mines, Johannesburg, South Africa, 11-14 September 1982; pp. 297-307.

127. Dou, L.; Chen, T.; Gong, S.; He, H.; Zhang, S. Rockburst hazard determination by using computed tomography technology in deep workface. Saf. Sci. 2012, 50, 736-740. [CrossRef]

128. Xu, N.W.; Li, T.B.; Dai, F.; Zhang, R.; Tang, C.A.; Tang, L.X. Microseismic Monitoring of Strainburst Activities in Deep Tunnels at the Jinping II Hydropower Station, China. Rock Mech. Rock Eng. 2016, 49, 981-1000. [CrossRef]

129. Young, R.P.; Maxwell, S.C.; Urbancic, T.I.; Feignier, B. Mining-induced microseismicity: Monitoring and applications of imaging and source mechanism techniques. Pure Appl. Geophys. PAGEOPH 1992, 139, 697-719. [CrossRef]

130. Xiao, Y.-X.; Feng, X.-T.; Hudson, J.A.; Chen, B.-R.; Feng, G.-L.; Liu, J.-P. ISRM Suggested Method for In Situ Microseismic Monitoring of the Fracturing Process in Rock Masses. Rock Mech. Rock Eng. 2015, 49, 343-369. [CrossRef]

131. Li, T.; Cai, M. A review of mining-induced seismicity in China. Int. J. Rock Mech. Min. Sci. 2007, 44, 1149-1171. [CrossRef]

132. Feng, G.-L.; Feng, X.-T.; Chen, B.-R.; Xiao, Y.-X.; Yu, Y. A Microseismic Method for Dynamic Warning of Rockburst Development Processes in Tunnels. Rock Mech. Rock Eng. 2015, 48, 2061-2076. [CrossRef]

133. Maxwell, S.C.; Rutledge, J.T.; Jones, R.H.; Fehler, M.C. Petroleum reservoir characterization using downhole microseismic monitoring. Geophysics 2010, 75, A129-A137. [CrossRef]

134. Young, R.; Collins, D.; Reyes-Montes, J.; Baker, C. Quantification and interpretation of seismicity. Int. J. Rock Mech. Min. Sci. 2004, 41, 1317-1327. [CrossRef] 
135. Ma, K.; Tang, C.; Wang, L.; Tang, D.; Zhuang, D.; Zhang, Q.; Zhao, J. Stability analysis of underground oil storage caverns by an integrated numerical and microseismic monitoring approach. Tunn. Undergr. Space Technol. 2016, 54, 81-91. [CrossRef]

136. Eaton, D.; Dusseault, M. Microseismic Monitoring Developments in Hydraulic Fracture Stimulation. In Proceedings of the Effective and Sustainable Hydraulic Fracturing, Brisbane, Australia, 20-22 May 2013; IntechOpen: Rijeka, Croatia, 2013.

137. Jiang, F.X.; Luo, X. Application of microseismic monitoring technology of strata fracturing in underground coal mine. Chin. J. Geotech. Eng. 2002, 24, 147-149.

138. Feng, X.T.; Chen, B.R.; Ming, H.J.; Wu, S.Y.; Xiao, Y.X.; Feng, G.L.; Zhou, H.; Qiu, S.L. Evolution law and mechanism of rockbursts in deep tunnels: Immediate rockburst. Chin. J. Rock Mech. Eng. 2012, 31, 433-444.

139. Yao, W.; Xu, Y.; Yu, C.; Xia, K. A dynamic punch-through shear method for determining dynamic Mode II fracture toughness of rocks. Eng. Fract. Mech. 2017, 176, 161-177. [CrossRef]

140. Li, X.; Zhou, Z.; Lok, T.-S.; Hong, L.; Yin, T. Innovative testing technique of rock subjected to coupled static and dynamic loads. Int. J. Rock Mech. Min. Sci. 2008, 45, 739-748. [CrossRef]

141. Zhang, Q.B.; Zhao, J. A review of dynamic experimental techniques and mechanical behaviour of rock materials. Rock Mech. Rock Eng. 2014, 47, 1411-1478. [CrossRef]

142. Xia, K.; Yao, W. Dynamic rock tests using split Hopkinson (Kolsky) bar system-A review. J. Rock Mech. Geotech. Eng. 2015, 7, 27-59. [CrossRef]

143. Yao, W.; He, T.; Xia, K. Dynamic mechanical behaviors of Fangshan marble. J. Rock Mech. Geotech. Eng. 2017, 9, 807-817. [CrossRef]

144. Manouchehrian, A.; Cai, M. Analysis of rockburst in tunnels subjected to static and dynamic loads. J. Rock Mech. Geotech. Eng. 2017, 9, 1031-1040. [CrossRef]

145. Zhu, W.; Li, Z.; Zhu, L.; Tang, C. Numerical simulation on rockburst of underground opening triggered by dynamic disturbance. Tunn. Undergr. Space Technol. 2010, 25, 587-599. [CrossRef]

146. Yilmaz, O.; Unlu, T. Three dimensional numerical rock damage analysis under blasting load. Tunn. Undergr. Space Technol. 2013, 38, 266-278. [CrossRef]

147. Yan, P.; Li, T.; Lu, W.B.; Chen, M.; Zhou, C.B. Properties of excavation damaged zone under blasting load in deep tunnels. Rock Soil Mech. 2013, 34, 451-457.

148. Lu, W.B.; Yang, J.H.; Yan, P.; Chen, M.; Zhou, C.B.; Luo, Y.; Jin, L. Dynamic response of rock mass induced by the transient release of in-situ stress. Int. J. Rock Mech. Min. Sci. 2012, 53, 129-141. [CrossRef]

149. Lu, C.-P.; Liu, G.-J.; Wang, H.-Y.; Xue, J.-H. Numerical Investigation of Rockburst Effect of Shock Wave on Underground Roadway. Shock. Vib. 2015, 2015, 867582. [CrossRef]

150. Li, Z.K.; Xu, Q.J.; Luo, G.F.; Wang, A.M. 3-D geo-mechanical model test for large scaled underground hydropower station. J. Hydraul. Eng. 2002, 5, 31-36.

151. Chen, Y.; Zhang, Y.; Li, X. Experimental study on influence of bedding angle on gas permeability in coal. J. Pet. Sci. Eng. 2019, 179, 173-179. [CrossRef]

152. Chi, X.; Yang, K.; Wei, Z. Breaking and mining-induced stress evolution of overlying strata in the working face of a steeply dipping coal seam. Int. J. Coal Sci. Technol. 2021, 8, 614-625. [CrossRef]

153. Chen, Y.; Zuo, J.; Liu, D.; Li, Y.; Wang, Z. Experimental and numerical study of coal-rock bimaterial composite bodies under triaxial compression. Int. J. Coal Sci. Technol. 2021, 8, 908-924. [CrossRef]

154. Chen, Y.L.; Zuo, J.P.; Liu, D.J.; Wang, Z.B. Deformation failure characteristics of coal-rock combined body un-der uniaxial compression: Experimental and numerical investigations. Bull. Eng. Geol. Environ. 2019, 78, 3449-3464. [CrossRef]

155. Gong, F.-Q.; Si, X.-F.; Li, X.-B.; Wang, S. Experimental Investigation of Strain Rockburst in Circular Caverns Under Deep Three-Dimensional High-Stress Conditions. Rock Mech. Rock Eng. 2019, 52, 1459-1474. [CrossRef]

156. Liu, D.; Li, D.; Zhao, F.; Wang, C. Fragmentation characteristics analysis of sandstone fragments based on impact rockburst test. J. Rock Mech. Geotech. Eng. 2014, 6, 251-256. [CrossRef]

157. Liu, D.Q.; He, M.C.; Wang, C.H.; Wang, J.; Yang, J.; Wang, Y. Experimental study on rock burst induced by dynamic load. J. China Coal Soc. 2016, 41, 1099-1105.

158. Du, K.; Tao, M.; Li, X.-B.; Zhou, J. Experimental Study of Slabbing and Rockburst Induced by True-Triaxial Unloading and Local Dynamic Disturbance. Rock Mech. Rock Eng. 2016, 49, 3437-3453. [CrossRef]

159. Su, G.; Feng, X.; Wang, J.; Jiang, J.; Hu, L. Experimental Study of Remotely Triggered Rockburst Induced by a Tunnel Axial Dynamic Disturbance Under True-Triaxial Conditions. Rock Mech. Rock Eng. 2017, 50, 2207-2226. [CrossRef]

160. Su, G.; Hu, L.; Feng, X.; Yan, L.; Zhang, G.; Yan, S.; Zhao, B.; Yan, Z. True Triaxial Experimental Study of Rockbursts Induced By Ramp and Cyclic Dynamic Disturbances. Rock Mech. Rock Eng. 2018, 51, 1027-1045. [CrossRef]

161. Yao, W.; Xu, Y.; Wang, W.; Kanopolous, P. Dependence of Dynamic Tensile Strength of Longyou Sandstone on Heat-Treatment Temperature and Loading Rate. Rock Mech. Rock Eng. 2016, 49, 3899-3915. [CrossRef]

162. Yang, R.; Ding, C.; Yang, L.; Lei, Z.; Zhang, Z.; Wang, Y. Visualizing the blast-induced stress wave and blasting gas action effects using digital image correlation. Int. J. Rock Mech. Min. Sci. 2018, 112, 47-54. [CrossRef]

163. Wu, B.; Chen, R.; Xia, K. Dynamic tensile failure of rocks under static pre-tension. Int. J. Rock Mech. Min. Sci. 2015, 80, 12-18. [CrossRef]

164. Wu, B.; Yao, W.; Xia, K. An Experimental Study of Dynamic Tensile Failure of Rocks Subjected to Hydrostatic Confinement. Rock Mech. Rock Eng. 2016, 49, 3855-3864. [CrossRef] 
165. Li, X.B.; Zhou, Z.L.; Ye, Z.Y.; Ma, C.D.; Zhao, F.J.; Zuo, Y.J.; Hong, L. Study of rock mechanical characteristics under coupled static and dynamic loads. Chin. J. Rock Mech. Eng. 2008, 27, 1387-1395.

166. Gong, F.Q.; Li, X.B.; Liu, X.L. Preliminary experimental study of characteristics of rock subjected to 3D coupled static and dynamic loads. Chin. J. Rock Mech. Eng. 2011, 30, 1179-1190.

167. Tang, Z.; Yao, W.; Zhang, J.; Xu, Q.; Xia, K. Experimental evaluation of PMMA simulated tunnel stability under dynamic disturbance using digital image correlation. Tunn. Undergr. Space Technol. 2019, 92, 103039. [CrossRef]

168. Li, C.X.; Guo, D.M.; Zhang, Y.T.; An, C. Compound-mode crack propagation law of PMMA semicircular-arch roadway specimens under impact loading. Int. J. Coal Sci. Technol. 2021. [CrossRef] 